\title{
The development and effects of the Ontario Farming and Food Production Protection Act, 1998
}

\author{
Anna Best* \\ *This paper was prepared for an environmental law class under the supervision of Professor B. James Deaton, \\ Department of Food, Agricultural and Resource Economics, Ontario Agricultural College, \\ University of Guelph, Guelph, Ontario, Canada

\begin{abstract}
Ontario's Farming and Food Production Protection Act, 1998, protects farmers from nuisance actions arising from agricultural methods that are considered "normal farm practices". Similar "right-to-farm" legislation exists in all Canadian provinces. It demonstrates the government's desire to protect the agricultural industry, likely for food security and economic reasons, and a willingness to prioritize its needs before those of nearby landowners with possible nuisance complaints. This legislation shifts the definition of "reasonable" used in nuisance complaints from farm neighbours to the farmer. It also transfers power from the courts to government agencies. The processes undertaken by agencies such as Ontario’s Normal Farm Practices Protection Board may be less lengthy, expensive and
\end{abstract} \\ adversarial than court litigation.
}

$\mathrm{O}_{\mathrm{i}}$ ntario's farms have decreased in number and increased in size over recent decades [1]. Competition in an unpredictable international market, livestock disease and urban sprawl has pressured many farmers to either intensify their operations or sell to residential developers. Because of economic and food security concerns, the provincial government has made efforts to reduce pressures on farmers. One way this has been accomplished is through the 1998 Farming and Food Production Protection Act, which protects farmers from nuisance actions arising from agricultural methods that are considered "normal farm practices".

In this paper I will first describe the current act, and discuss its history and the reason for its development. Finally, I will examine the act's effect on the agricultural community and non-farm rural residents.

\section{OVERVIEW OF THE ACT}

The following is taken from the preamble of Ontario's Farming and Food Production Protection Act [2]:

It is desirable to conserve, protect and encourage the development and improvement of agricultural lands for the production of food, fibre and other agricultural or horticultural products.

Agricultural activities may include intensive operations that may cause discomfort and inconveniences to those on adjacent lands.

Because of the pressures exerted on the agricultural community, it is increasingly difficult for agricultural owners and operators to effectively produce food, fibre and other agricultural or horticultural products.

It is in the provincial interest that in agricultural areas, agricultural uses and normal farm practices be promoted and protected in a way that balances the needs of the agricultural community with provincial health, safety and environmental concerns.

The Farming and Food Production Protection Act (FFPPA) was passed in 1998, amended from the 1988 Farm Practices Protection Act. Often referred to as "right-to-farm" legislation, the act declares that farmers cannot be held liable for nuisance actions brought against them for odour, noise, dust, flies, light, smoke, or vibration, if the nuisance arose from what is considered a "normal farm practice". All Canadian provinces have similar legislation [3].

Nuisance is a common-law tort concerning a person's actions that interfere with another person's use and enjoyment of their property [4]. Its focus is on whether the interference with the plaintiff is reasonable, regardless of care taken by defendant or whether the defendant's actions are reasonable in themselves. Because many agricultural practices produce potential irritants like odour, noise and dust, regardless of the diligence of the farmer, farmers are often at risk of nuisance lawsuits [4]. Under traditional common law, courts could grant adjacent landowners 
injunctions against farmers or order damages to be paid for these nuisances; these restrictions and costs, in addition to court time and court costs, could force an agricultural operation to close. These factors are likely the reason why right-to-farm legislation has focussed on protecting farmers from nuisance actions [4].

One reason why these conflicts have become more important in recent decades is the influx of non-farm residents to agricultural areas. These residents may have high expectations of quiet and fresh air in the countryside but are unfamiliar with the reality of manure and noisy tractors $[4,5]$. Another is the change in agriculture itself, as many operations become more intensified and thus more likely to cause nuisances to new and old neighbours alike [4,5]. As noted in the preamble, the FFPPA was brought into force intending to lessen pressures on farmers and thus on Ontario's agricultural production. The act notes that agricultural intensification is taking place and although it admits that this can disturb nearby residents, it is in the interest of the province to allow agricultural methods, when considered "normal", to continue despite this disturbance.

The FFPPA establishes a "Normal Farm Practices Protection Board" (NFPPB) with the authority to review nuisance complaints against farmers, conduct hearings and rule whether the nuisance-causing activity is a normal farm practice. If so, the complaint is dismissed and no court may issue injunctions or other orders to stop the farmer from continuing the practice. If not, the Board can order the farmer to cease the practice or make modifications. The lawsuit protection does not apply if the defendant has a charge related to the nuisance pending under the Environmental Protection Act, the Pesticides Act, the Health Protection and Promotion Act, or the Ontario Water Resources Act. Also, a practice cannot be considered "normal" if it is in violation of the Nutrient Management Act.

Municipal by-laws, when restricting farm practices, are also declared in the FFPPA to not apply when the practice is considered "normal" by the Board. However, the Board does take several factors into consideration in its decision: the purpose of the by-law, the effect of the farm practice on abutting lands and neighbours, whether the by-law reflects a provincial interest and the specific circumstances pertaining to the site [2].

Anyone wishing to bring forth a complaint may apply to the Board, which can investigate the issue by means such as interviews or site examination. A mandatory conflict resolution process is undergone before this stage, aided by agricultural engineers from the Ontario Ministry of Agriculture, Food and Rural Affairs (OMAFRA) [6]. A hearing is then held if the complaint was made in good faith and was not a trivial matter; both sides present their case and expert witnesses may be called [4]. Right-to-farm legislation does not prohibit the applicant from bringing a nuisance action against the defendant in court, but the court must give "primary consideration" to the Board's decision [4].

\section{DEVELOPMENT OF THE ACT}

\section{Rise of right-to-farm laws in Canada}

Right-to-farm legislation has been passed in all Canadian provinces since Manitoba enacted the Nuisance Act in 1976; the most recent law came into effect in Newfoundland and Labrador in 2003 [3]. One of the events leading to the widespread rise of these statutes was two New Brunswick lawsuits lost by farmers in the early 1980s [7]. The province's agricultural department responded "with a statement strongly condemning the unreasonable expectations urban migrants have of the character of the countryside and activities of farmers" [7]. Provincial standards were then set for manure management and nuisance actions could not be brought against farmers in compliance with them.

Caldwell et al. [5] refer to this early legislation, which only endeavoured to prevent nuisance actions, as "first generation" and consider the difference with later legislation, including Ontario's right-to-farm acts. They consider "second generation" legislation to have a broader, more preventative aim, including the general promotion of peaceful interaction between rural inhabitants by mandating minimum separation distances between farming and housing, limiting severances on agricultural land and making mediation a mandatory step before hearings can be held. Similarly, Kalmakoff [4] remarks that right-to-farm legislation arose partially from the realization that "the traditional litigation process - with its highly polarized adversarial system, exorbitant costs, unrealizable delays and often unpredictable results - is not necessarily the best means of resolving disputes between neighbours”. Although the relatively small actual number of nuisance suits brought against farmers might not seem to justify the legislation, most complaints are dealt with informally, so the legislation is pre-emptively addressing the potential for conflict [4].

\section{Development of Ontario's statutes}

Ontario's first law of this kind was the Farm Practices Protection Act, passed in 1988 [8]. It protected farmers employing normal farm practices from nuisance suits concerning only odour, noise and dust and did not include exemptions from municipal by-laws. Exemptions from restrictive by-laws and protection from nuisance actions concerning flies, light, smoke, or vibration were added in the stronger 1998 act. In addition, the 1998 FFPPA states that a court may never grant an injunction or prevent operation of a farm because it causes a disturbance, whether or not the operation uses normal farm practices (it is implied that it may still award damages regarding a non-normal practice). The cessation of the operation or practice in question is thus left to government agencies; this change more fully completes the transfer of control over farm practices from court decisions to the government-run NFPPB.

A more subtle change involves the link between the nuisance protection and compliance by the farmer with other 
statutes [1] (namely the Environmental Protection Act, the Pesticides Act, the Health Protection and Promotion Act and the Ontario Water Resources Act). Under the 1988 act, protection from nuisance applied if the practice in question was not in violation with these statutes, while under the FFPPA, nuisance protection applies unless there is already a charge pending against the farmer under the aforementioned acts.

In 2002, another amendment was made that dictates that farm practices must comply with the 2002 Nutrient Management Act in order to be considered normal. Changes in nutrient management legislation had an additional impact on the NFPPB: according to McCormally [3], with the creation of an information line to handle complaints about manure odours, annual complaints to the NFPPB dropped from 675 to 89 between 2005 and 2006. However, complaints in 2007 rose to 203 [6], so the creation of the information line did not have as drastic an effect as shown by McCormally.

\section{CONSEQUENCES OF THE ACT}

\section{Litigation prevention and conflict resolution}

In reviewing Canada-wide legal cases in the years up to 1999, Kalmakoff [4] found that provincial right-to-farm laws had been successful at preventing nuisance suits against farmers; at that time there had been no court cases in which the liability protection was applied. In Ontario, only one case heard by the NFPPB has gone on to litigation [6]. The Board received 203 complaints in 2007 to 2008, but most were dealt with through OMAFRA conflict resolution processes and only six were presented in NFPPB hearings; there are on average four hearings per year [6]. However, since commonlaw torts beside nuisance are not covered by the FFPPA, litigation against farmers may still be pursued under other torts [4].

Between 1990 and 2008, there have been 61 hearings in Ontario: the Board ruled for the farmer in 14 of these and against the farmer in 22 of them and the remainder were closed for various reasons [6]. Similarly, in reviewing 37 cases heard by right-to-farm boards across Canada between 1989 and 1999, Kalmakoff [4] found in 23 cases the nuisance-causing practice was ruled not to be normal, compared to nine cases where the practices was considered normal. These results seem support a lack of bias towards farmers within these boards [4]. The Ontario results particularly seem to point to the effectiveness of OMAFRA's negotiation and mediation processes in preventing conflicts from escalating.

The use of right-to-farm legislation and Board hearings as opposed to only the court system to determine acceptable farming standards is advantageous to the agricultural community [4]. The NFPPB can and has ordered farmers to cease or modify their methods and places pressure on farmers to comply with other regulations; however, farmers are now protected from the risk of expensive lawsuits and possibly harsh judge decisions. Ontario's two right-to-farm statutes have been clearly welcomed by the agricultural community $[9,10,11]$.

The FFPPA and NFPPB allow refinement of evolving concepts of acceptable farm practices through the hearings process. In a 2001 hearing, the NFPPB settled a by-law conflict by creating standards, regarding the amount of land for manure management needing to be under the long-term control of the farmer, that it expected future Board hearings to abide by. The decision implied that farmers ought to follow these standards and that municipalities ought to create future by-laws taking these standards into account [5]. This evolution of agricultural standards based on real conflicts is something that could also be accomplished through the courts, but might occur more slowly due to the cost of litigation to potential plaintiffs and would also be subject to the judges and lawyers involved and the unpredictable nature of some court cases.

\section{Legal shift caused by right-to-farm legislation}

As mentioned above, nuisance is a flexible, plaintiff-oriented tort in which the court may rule against the defendant regardless of the care taken by the defendant [4]. With the implementation of the FFPPA, the court may now only rule against the defendant if it is shown that the defendant farmer's actions were not normal, regardless of the disturbance that may be caused to the plaintiff even by normal practices. This in effect changes nuisance "from a nofault, strict liability tort into a fault-based scheme of liability”, similar to negligence, as it is now dependent on the reasonability of the defendant's action [4].

Strict liability is a standard of common law under which the defendant is responsible for the consequences of his or her actions regardless of his or her intentions or diligence. Negligence, on the other hand, is a standard of liability in which the defendant "had an obligation to the plaintiff to act reasonably" and did not do so, causing harm to the plaintiff [12]. One key difference between nuisance under the FFPPA and negligence, however, is that an action is judged as negligent under common law by comparing it to what any "reasonable person" would do, while in a nuisance suit against a farmer under the FFPPA, the farmer's action is compared to what the "average farmer" currently does in Ontario [4]. This standard strives to protect what is reasonable according to typical Ontario farmers, not necessarily what is reasonable according to their neighbours. Predictably, then, conflict over right-to-farm legislation arises from this shift in whose version of "reasonable" is to be protected.

Since "normal" farm practices are not guaranteed, simply because they are common, to be environmentally friendly or easy for neighbours to live with, critics have suggested that "sound" or "reasonable" farm practices should be the standard rather than "normal" farm practices $[4,13]$. This could involve a shift in focus to practice that "maintain ecosystem stability" and "improve the productivity or quality 
of use of agricultural resources" [4], or that focus more on preserving farmland rather than specific farm methods [13].

This level and type of reasonableness, however, might be difficult to set as it would have to be chosen according to evolving scientific research as well as knowledge of what is possible for Ontario's farmers to achieve. As central and essential the food production industry is to life, standards could not be set so high as to force agriculture to cease altogether. As shown by the "provincial interest" invested in Ontario's agricultural industry, farming is considered too important to allow the court and market forces to have total sway over its viability. Already heavily subsidized [14], the economic, cultural and food security issues presented by agriculture are considered by the government to outweigh the loss of individuals' rights to live free of nuisance interference, as well as the potential environmental damage caused by not enforcing higher standards.

\section{Contrast with common-law}

Advocates of common-law criticize this loss of protection for individuals to use their property free from interfering nuisances [1,3]. The erosion of the ability of individuals to use the court to defend their rights, it is argued, allocates too much power to government agencies which could have bad policies, or be biased or ineffectual in enforcing its own regulations; this puts individuals and the environment at risk of pollution $[1,3]$.

While right-to-farm legislation certainly transfers power from court decision-making to government agencies with different priorities, there are some interesting contrasts between the legislation and common-law traditions. One concept of common law is that judges often do consider "the character of the neighbourhood" in which a disturbance occurs in their decision [1]. This appears similar to arguments made by proponents of right-to-farm legislation regarding the need to protect farmers from the complaints of ex-urbanite rural residents, unused to the realities of agriculture. An argument could be made that because location in an agricultural area may already be taken into account in the courts, strong legislation like the FFPPA is unnecessary; it could also be argued that this means right-tofarm statutes are not so extremely removed from common law.

Another contrast with common-law tradition is the decision by multiple judges, since the late 1600 s, not to hold farmers liable for nuisance caused by fire unless the farmer was also negligent [1]. Judges commented on the necessity of burning stubble and of clearing new farmland, the contribution of agricultural expansion to the public good and the unpredictable effects of wind on fire. It was also remarked that holding farmers liable in this situation would discourage agriculture [1]. These comments are very similar to the arguments that right-to-farm legislation is based on regarding the necessity of agriculture and the undesirability of discouraging it.

\section{CASE STUDIES}

\section{Knip vs. Biddulph}

To illustrate the application of the FFPPA and its effects, I will briefly describe two case studies. The first is a 1998 case concerning a municipal by-law that restricted farm practices, as detailed by Caldwell et al. [5]. The township of Biddulph became concerned about the environmental effects of manure and created a committee of citizens to help research the information needed to create a by-law to address the concerns. It passed a by-law ruling that a single site could hold no more than 500 livestock units, that every 1.5 livestock units required the farmer to have one acre of land available for manure application and that the farmer must own two third of this total required land. Mr. Fred Knip planned to build a 750-livestock-unit hog barn and did not personally own the required amount of land and the conflict was brought to the NFPPB.

The Board ruled that the size of Mr. Knip's proposed barn was a normal farm practice and that a personalized nutrient management plan should be used to determine the land base necessary to spread manure, not a set ratio, because the necessary amount of land changes based on soil type. It also ruled that "long-term control", rather than personal ownership of the land base, should be required. The Knip family did have this amount of land under long-term control. However, the township appealed this decision and the appeal was to be heard by the Ontario Divisional Court. At this point, the hog market faced a sharp decline; the Knip family decided they did not have the necessary financing to continue with the appeal and decided not to go through with their planned expansion.

This case demonstrates a number of issues surrounding right-to-farm conflicts. For one, ordinary township residents, who were understandably concerned for the environment, but may have been unfamiliar with agriculture, performed the background research for the bylaw and some of its findings were ruled to be arbitrary by the NFPPB [5]. For another, the unpredictable financial nature of farming and the high cost to the Knips to continue with the township's appeal, underline the claims by right-to-farm proponents that farmers need protection from extra costs and difficulty.

Another issue is the effectiveness of the Board's proposition of a nutrient management plan. Proponents of the farmer state that Knip was "an environmentally-sensitive farmer with 25 years experience" and had "completed an Environmental Farm Plan and taken an OMAFRA nutrient management course" [9]. They consider this to be evidence that the expansion would be environmentally-friendly. Proponents of the township, however, may worry that government-run nutrient management plans would not be enforced [1]. With no right-to-farm legislation in place, a nuisance action could be brought against Knip for the effects of the expansion regardless of whether a nutrient management plan was created or adhered to. 


\section{Gunby vs. Mushroom Producers Cooperative}

As described by McLaren [15], a case with a less clear-cut decision by the NFPPB occurred in 1999, when two neighbours of the Mushroom Producers' Cooperative filed a complaint regarding the "extremely noxious odours" produced by the operation. The Board found that the applicants' "enjoyment of life had been substantially diminished" as the odours were so strong they could cause nausea and prevented the applicants from spending time in their yards or entertaining visitors. The Board considered evidence that in Europe, the odour-creating production of mushroom substrate is kept indoors and aerated floors are used to prevent the anaerobic composting process that worsens odours. These methods had also been recently required by legislation in British Columbia.

Because the necessary technology was new to Canada, the NFPPB ruled that the current methods used by the Mushroom Producers' Cooperative were considered normal, but only "marginally acceptable". The Board urged the mushroom industry to improve their production practices and stated that future Board rulings may mandate the new technology as its use becomes more common.

This case shows the possible impact of prioritizing the normalcy of farm practices over the effect of the practice on others. The odours in question did cause a substantial harm to the applicants, but because the technology necessary to mitigate this was not yet considered normal, the applicants were unable to obtain damages or an injunction. The producers were encouraged to update their technology voluntarily and advised that this may be required in the future; however, under a common law court decision, they might have been ordered to cease the operation or to install new technology immediately. This would also have provided an incentive to other mushroom farmers to do the same in order to avoid similar lawsuits.

A similar case of nuisance due to odour, described in Brubaker [16], and Walker [6], involved a lawsuit against Greenwood Mushroom Farms which occurred prior to involvement of the NFPPB. The court awarded damages to the plaintiffs but did not grant them an injunction; later, after years of negotiations partly mediated by the NFPPB, the parties came to an agreement involving the installation of new technology and the monitoring of odours by Greenwood Mushroom Farms.

\section{CONCLUSION}

Right-to-farm legislation in Canada, existing since 1976, has evolved over the years and will likely become more significant as non-farm, rural residents increase in number and farm operations increase in size. Ontario's Farming and Food Production Protection Act protects farmers who use normal farm practices from by-law restrictions and nuisance actions stemming from those practices.

The legislation has been criticized for the removal of individual common-law rights and the environmental risks posed by allowing certain farm practices. Prioritizing normal farm practices over the complaints of non-farm rural residents protects the farmer from paying damages among other consequences. The legislation has been positively received by the agricultural community because it is support necessary for a viable agricultural industry in Ontario, which can be linked to economic and food security concerns.

The vast majority of complaints in Ontario have been resolved through mediation, with those formally heard by the Normal Farm Practices Protection Board slightly more often found in favour of the applicant. Board processes may offer an alternative to litigation that is less adversarial, more quickly resolved and less costly to plaintiffs and defendants. However, a balance between the needs of farm neighbours and of farmers needs to be maintained. As the demographics of Ontario's countryside and the nature of its agricultural operations change over time, so will the relationship between law, agriculture and the environment. Interests in protecting the viability of the agricultural industry will be continually rebalanced with the need to reduce environmental risks and promote peaceful relationships between rural land users.

\section{REFERENCES}

1. Brubaker, Elizabeth. 2007. Greener Pastures: Decentralizing the Regulation of Agricultural Pollution. Toronto: University of Toronto Centre for Public Management Monograph Series.

2. Farming and Food Production Protection Act, S.O. 1998, c. 1.

3. McCormally, Patrick. July 2007. Right-to-Farm Legislation in Canada. Environment Probe. Online: http://www.probeinternational.org/envirowaterarticles/ri ghttofarmcanada.pdf [Accessed Dec. 8 2009].

4. Kalmakoff, Jonathan J. 1999. “The right to farm”: A survey of farm practices protection legislation in Canada. Saskatchewan Law Review Vol. 62, pp. 225 268.

5. Caldwell, Reid, and Weir. June 2004. The Normal Farm Practices Protection Board. Final Report: Conflict Resolution in Rural Ontario. University of Guelph. Online:

http://www.waynecaldwell.ca/Projects/Conflict/right\%2 0to\%20farm\%20practices.pdf [Accessed Dec. 9, 2009].

6. Walker, Glenn C. June 27, 2008. Annual Report of the Normal Farm Practices Protection Board: April 1st, 2007 - March 31st, 2008. Normal Farm Practices Protection Board, Ontario Ministry of Agriculture, Food and Rural Affairs. Online: http://www.omafra.gov.on.ca/english/engineer/nfppb/an nual_report2007.pdf [Accessed Dec. 6 2009].

7. Lapping, M. and Leutwiler, Nels. 1987. Agriculture in Conflict: Right-to-Farm Laws and the Peri-Urban Milieu for Farming. In Lockeretz, W. (ed.). Sustaining Agriculture Near Cities. Boston: Soil and Water Conservation Society, 209-218. 
8. Farm Practices Protection Act, S.O. 1988, c. 62.

9. Eastern Ontario Agrinews. March 1999. Right-to-farm put to test. Eastern Ontario Agrinews Opinion/Editorial. Online: http://www.agrinewsinteractive.com/archives/article546.htm [Accessed Dec. 10, 2009].

10. Tobin, Bernard. No date. Right to farm rules under review. Farm \& Country. Agricultural Publishing Company Ltd. Online: http://www.agpub.on.ca/text/m14_nws1.htm [Accessed Dec. 10 2009].

11. Ontario Federation of Agriculture. 2009. Right to Farm. Ontario Federation of Agriculture. Online: http://www.ofa.on.ca/index.php?p=93\&a=121 [Accessed Dec. 10 2009].

12. Muldoon, Paul; Lucas, Alastair; Gibson, Robert B.; and Pickfield, Peter. 2009. An Introduction to Environmental Law and Policy in Canada. Toronto: Emond Montgomery Publications Limited.
13. MacRae, Rod, and Cuddeford, Vijay. March 1999. A Sustainable Food \& Agriculture Agenda for Ontario. Prepared for The Environmental Agenda for Ontario Project. Online: http://www.cielap.org/pdf/EnvAgenda_FoodAg.pdf [Accessed Dec. 8 2009].

14. Brubaker, Elizabeth. May 7, 2002. Restoring the family farm to economic and environmental sustainability. Environment Probe. Online: http://www.environment.probeinternational.org/campaig n-letters/property-rights/restoring-family-farmeconomic-and-environmental-sustainability [Accessed Dec. 10 2007].

15. McLaren, David. 1999. Can agri-business take a hint from the Normal Farm Practices Protection Board? Intervenor Vol. 24, No. 4, p. 12.

16. Brubaker, Elizabeth. Aug. 21, 2004. Invasive Agriculture. The Financial Post. Online: http://www.environment.probeinternational.org/news/ag riculture/invasive-agriculture [Accessed Dec. 10, 2009]. 